\title{
Remote sensing of the impact of reindeer grazing on vegetation in northern Fennoscandia using SPOT XS data
}

\author{
JUKKA KÄYHKÖ and PETRI PELLIKKA
}

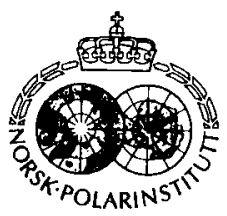

Käyhkö, Jukka \& Pellikka, Petri 1994: Remote sensing of the impact of reindeer grazing on vegetation in northern Fennoscandia using SPOT XS data. Polar Research 13, 115-124.

Digital image analysis and SPOT XS satellite data recorded on 1 August 1991 were used to monitor vegetation in the border region between Enontekiö municipality, Finland, and Kautokeino municipality, Norway. A supervised classification on the red wave length channel was undertaken using training areas for maximum likelihood classifier to produce seven spectral land cover classes. The classification revealed great differences in vegetation between Finland and Norway. The largest difference was the lack of Cladinalichens on the Finnish side of the border. The area on the Finnish side is used for grazing all year round, while the area on the Norwegian side is a winter range only. According to official data for the local reindeer population, the average annual grazing pressure (head/area/time) is higher on the Norwegian side of the reindeer fence. The Finnish grazing practice is believed to have a detrimental impact on the vegetation, and has lead to pasture land degradation.

Jukka Käyhkö, Department of Geography, Laboratory of Physical Geography, P.O. Box 9 (Siltavuorenpenger 20A), SF-00014 University of Helsinki, Finland (Present address; Postgraduate Research Institute for Sedimentology, The University, P.O. Box 227, Whiteknights, Reading RG6 2AB, U.K.); Petri Pellikka, Department of Geography, University of Oulu, Linnanmaa, SF-90570 Oulu, Finland (Present address: Institute for Geography, Department for Geographical Remote Sensing, University of Munich, Luisenstrasse 37, D-80333 Munich, Germany).

\section{Introduction}

The line of the border between Norway and Finland is clearly visible on satellite images due to the sharp contrast in vegetation. On the Norwegian side, highly reflectant Cladina spp. lichens grow widely, whereas the heaths on the Finnish side consist of much darker Stereocaulon spp. and Cetraria spp. lichens, grasses and dwarf shrubs such as Empetrum hermaphroditum Hagerup and Betula nana L. In Fennoscandia Cladina lichen heaths are the most important source of forage for reindeer during winter, when no green plants are available. As intensive reindeer Rangifer tarandus domesticus husbandry has been known to modify vegetation cover, the possible degradation of lichen-rich pasture lands due to over-grazing has become a major fear.

Reindeer range inventories using remote sensing methods have been undertaken during the last decade by several researchers. In Norway, Tømmervik \& Lauknes (1987) and Johansen \&
Tømmervik (1990) have used Landsat TM and MSS imagery in supervised and unsupervised classification, with the best results achieved with the latter approach. In Finland, range inventory has been carried out in various pilot areas in different vegetation zones of the reindeer herding area (Nieminen \& Kumpula 1991; Rantanen et al. 1989). The inventory method based on interpretation of Landsat TM imagery was successful for areas rich in lichens. On a large scale, the entire reindeer herding area in Finland has been interpreted using Landsat TM imagery as a part of the classification of forests and land-use by the National Board of Survey in 1991.

In North America, the ranges of reindeer, muskox and bison have been studied using remote sensing methods. During the last decade the material used has mainly been Landsat TM data with different channel combinations and classification procedures (Henry et al. 1986; Ferguson 1991; Henry \& Gunn 1991; Matthews 1991). In addition SPOT imagery has been used, for 
example, in muskox habitat mapping (Pearce 1991).

Remote sensing studies of vegetation normally use specific wavelength regions to provide information about the vegetation present in the study area. At the visible/near-infrared part of the spectrum, there are some characteristic wavelength regions where leaf optical properties and background optical properties control the plantcanopy spectral reflectance (Tucker \& Sellers 1986). Chlorophyll $a$ and $b$ and carotenoids within healthy plants (including lichens) absorb light energy throughout the visible part of the spectrum, but have two definite absorption peaks, one in the blue region $(400-500 \mathrm{~nm})$ and the other in the red region $(600-700)$. In between, at the green wavelength region $(500-600 \mathrm{~nm})$, the absorption is weaker, causing a minor peak in the reflection curve. At the near-infrared wavelength region $(700-740 \mathrm{~nm})$, the absorption ceases because leaf scattering mechanisms cause a strong reflectance. The scatter is caused by refractive index differences between intercellular air spaces, hydrated cells and air cuticle (Hodanova 1985; Tucker \& Sellers 1986).

SPOT XS imagery gives a potential alternative

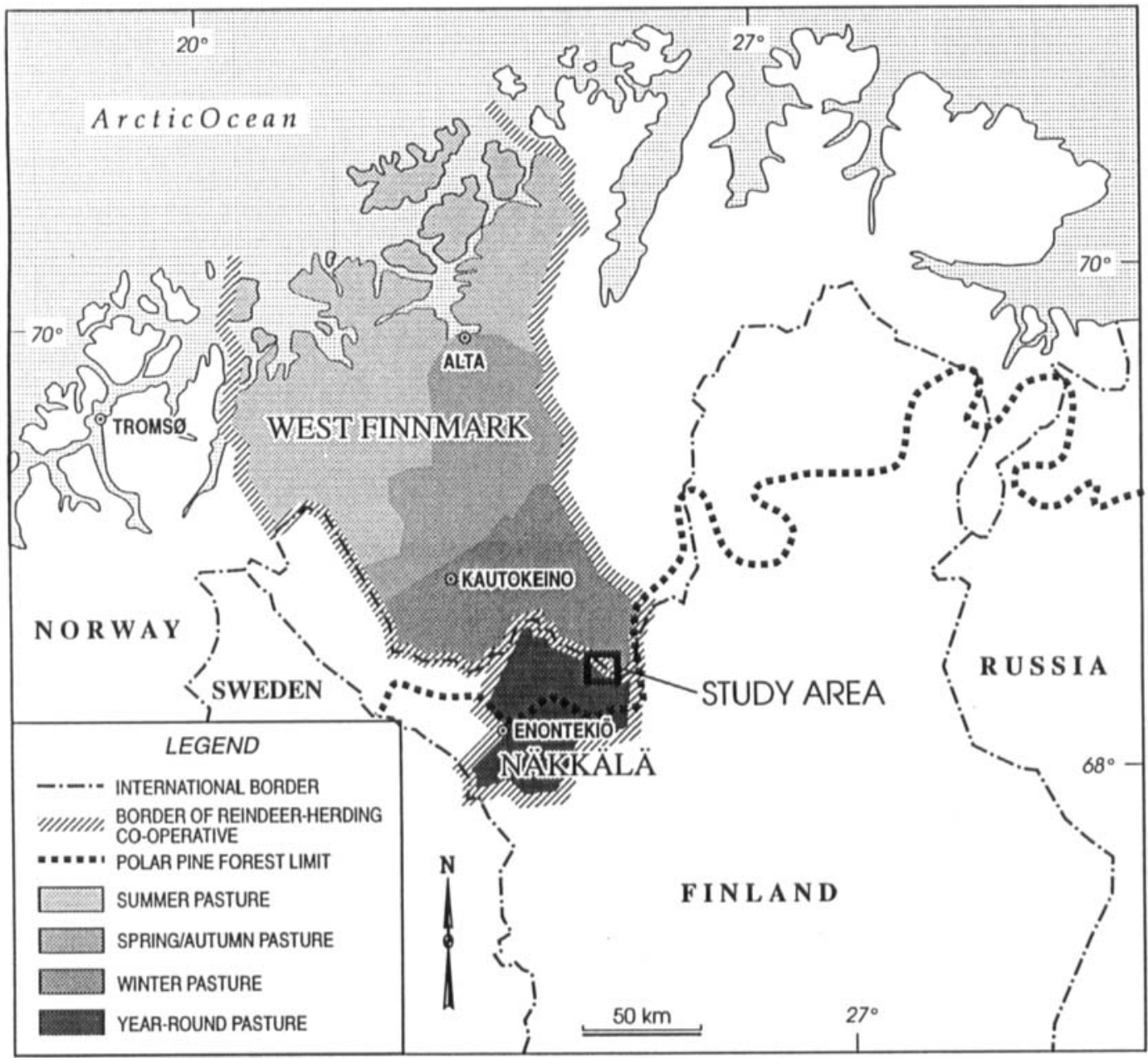

Fig. 1. Study area in Northern Fennoscandia, just north of the polar pine forest limit. The geo-corrected SPOT XS image (study area) covers an area of $157 \mathrm{~km}^{2}$, half of which belongs to the winter grazing area of Western Finnmark reindeer herding cooperative in Norway. The southern half belongs to the Näkkälä reindeer-herding co-operative in Finland. 
to Landsat TM with its better areal resolution $(20 \mathrm{~m}$ vs. $30 \mathrm{~m})$. The objectives of this study are to answer the following questions: (1) How do the changes in vegetation cover caused by yearround reindeer grazing influence the spectral signatures of SPOT XS satellite data, and (2) Could the multispectral SPOT XS data with its three bands be a useful tool in classifying Fennoscandian subarctic mountain heath vegetation.

\section{Study area}

The study area lies across the border between Norway and Finland some $250 \mathrm{~km}$ south-east of Troms $\varnothing$, approximately $68^{\circ} 40^{\prime} \mathrm{N}, 24^{\circ} 50^{\prime} \mathrm{E}$ (Fig. 1). On the Norwegian side of the border lies the winter grazing area of the West Finnmark reindeer herding co-operative (reinbeiteområde). The total area of the co-operative is $24,025 \mathrm{~km}^{2}$, with the winter grazing area covering $5,294 \mathrm{~km}^{2}$. On the Finnish side of the border lies the Näkkälä reindeer herding co-operative (paliskunta) with an area of $3,539 \mathrm{~km}^{2}$. There are no separate seasonal grazing areas in Näkkälä. The border line follows the main water divide between the Arctic Ocean and the Baltic Sea.

Some 9,000 years ago, during the melting of the Fennoscandian ice sheet, the glacial lake, Käkkälö, existed in the southwestern part of the study area. The margin of the ice sheet retreated south-westward and the lake was formed between the ice sheet and the water divide (Kujansuu 1967). The terrain is relatively flat, with elevations ranging from 370 to 530 metres. Most of the area is covered by till, but occasionally glaciolacustrine, glaciofluvial and aeolian deposits crop out (Olsson 1957; Seppälä 1966; Käyhkö 1991).

The study area covers $157 \mathrm{~km}^{2}$ and is situated just north of the polar limit of Scots pine Pinus sylvestris $\mathrm{L}$. forest. The sparse forests or scrubs of the study region consist of mountain birch Betula pubescens subsp. tortuosa (Ledeb) Nyman, and according to Hämet-Ahti (1963) the area is within the continental sub-alpine birch zone. The summits of the highest fells are treeless mountain heath, while the lowlands are mountain birch scrub or bog. Parts of the glaciofluvial esker complex on the lowlands are either treeless heath or aeolian blowouts (deflated surfaces) without vegetation cover.
In the Norwegian uplands, the ground cover consists of light-coloured reflective lichens, mostly Cladina species such as $C$. stellaris, $C$. mitis and $C$. rangiferina with scattered dwarfshrubs, Arctostaphylos alpina, A. uva-ursi, Betula nana and Empetrum hermaphroditum (Johansen \& Tømmervik 1990). On the Finnish fells, Cladina species have almost vanished being replaced by other Cladonia families, e.g. Cetraria and Stereocaulon (C. nivalis (L.) Ach., S. alpinum Laur., $S$. paschale (L.) Hoffm.), dwarf-shrubs and grasses such as Festuca ovina L.

\section{Material and methods}

The SPOT case study was based on part of the SPOT XS satellite image 57-207, recorded on 1 August 1991, at 10:08 GMT (Fig. 5). The HRV sensors of the SPOT satellite record reflectance information from the earth's surface in three spectral bands and in $20 \mathrm{~m} \times 20 \mathrm{~m}$ cells using three wavelengths, green (band 1, 500-590 nm), red (band 2, 610-680 nm) and near-infrared (band 3, 790-890 nm). Atmospheric corrections were not implicated because only one image was examined. The ground truth data of the classification was based on the interpretation of SPOT satellite image prints $(1: 50,000)$, topographic maps $(1: 20,000,1: 50,000,1: 100,000)$, false colour aerial imagery $(1: 30,000)$, bog overlay $(1: 100,000)$ and field data. The SPOT data were analysed using the Idrisi image analysis programme on a personal computer with an Intel 80486 processor.

The information was studied channel by channel and as a three band composition. A supervised pre-classification, using maximum likelihood classifier, was made of the three channel composition and of the red channel. Topographic maps and aerial imagery were used as reference data for training areas. Altogether seven terrestrial land cover classes plus a water class were produced in the classification procedure: (1) deflated area; (2) lichen heath; (3) lichen and dwarf-shrub heath; (4) dwarf-shrub and grass heath; (5) Empetrumheath; (6) mountain birch forest; (7) bog; and (8) water. The results were plotted as $1: 25,000$ prints for use during the field study.

In the field, the pre-classifications were tested by comparing the classification results of each pixel with the actual vegetation type growing on the site. This was undertaken for all classes on 

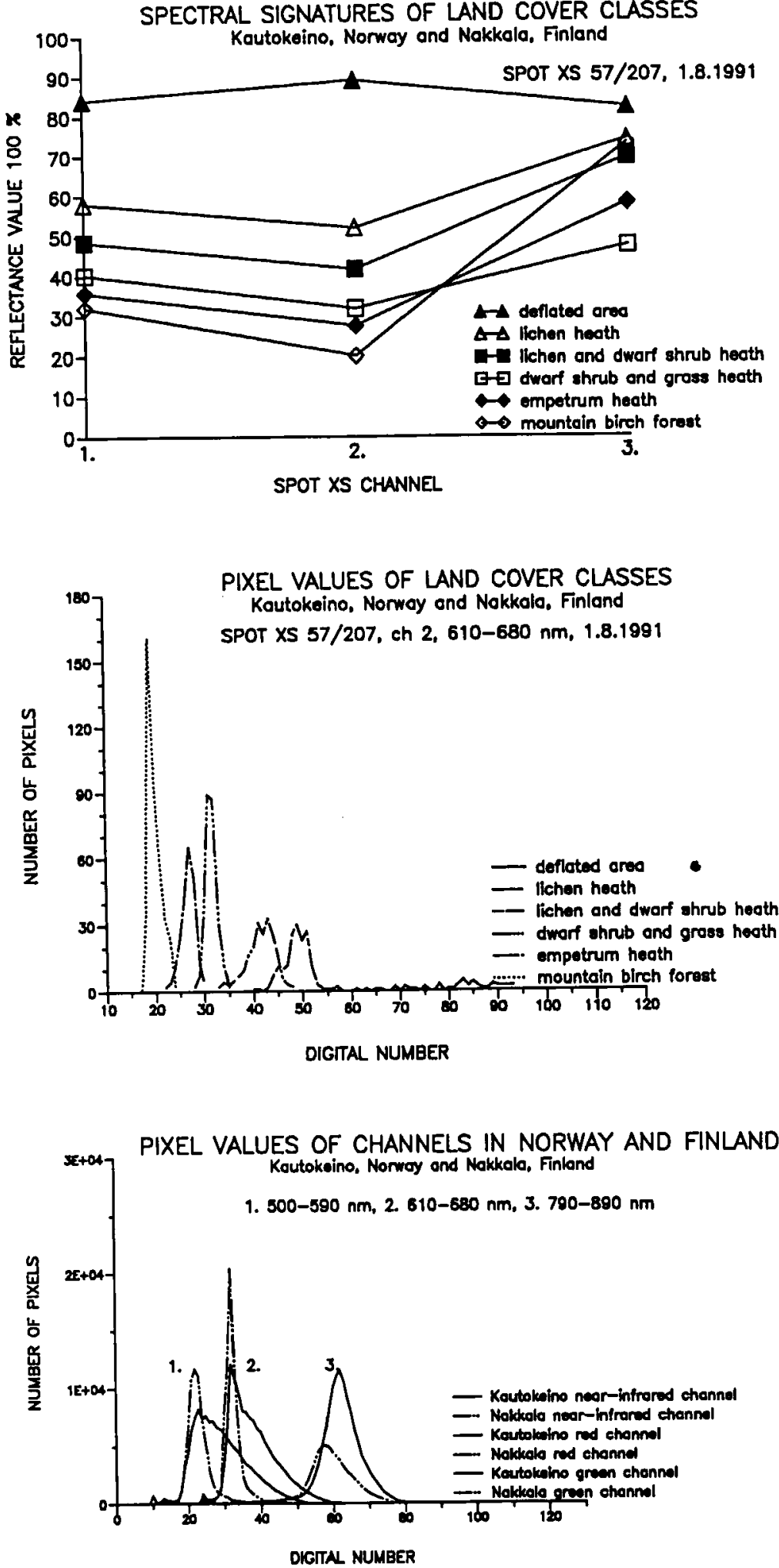

Fig. 2. Reflectance values (\%) of land cover classes in each SPOT XS channel. Channel no. 2 (red) gives the best resolution between land cover classes and was used in the final classification. No atmospheric correction was implicated to the data.

Fig. 3. Pixel grey values of land cover classes in red wavelength channel.
Fig. 4. Pixel grey values of SPOT XS channels in Finnish and Norwegian sides of the study area. 
several sites, but no statistical analyses were made. More ground truth data were collected and large homogenous areas were selected for use as training areas in further supervised classification. The most significant plant species influencing the reflectance of each pixel were described and identified, and the ground data collected during the field study were used as training areas for maximum likelihood classifier. The spectral data were overlaid and geo-corrected with reference to a bog overlay scanned from Finnish and Norwegian topographical maps. The final classification routine was performed on the red channel (2) only, producing six terrestrial land cover classes (bogs excluded).

\section{Results}

Due to strong chlorophyll absorption at visible wavelengths, green vegetation occurs dark on SPOT channel 1 (green) and even darker on channel 2 (red) (Fig. 2). At near-infrared wavelengths (channel 3), chlorophyll absorption is weak, and vegetation appears bright. This pattern is most apparent on birch forest class because of the large leaf area. As Cladina lichens have strong optical reflectance both at visible and near-infrared wavelengths, they appear bright on all SPOT channels. Studies made with an imaging spectrometer (Satterwhite et al. 1985) also prove an increase in reflectance for lichens at wavelengths longer than $700 \mathrm{~nm}$. Thus, the independent use of the NIR channel could not be of any help in separating the lichen heaths from the birch forests because of high reflection of both vegetation types (Fig. 2). Moreover, upon incorporation of the NIR channel within the multichannel procedure, the classification result deteriorated. Based on visual comparisons between the ground truth data and the classification results, the independent use of the red band proved to give the most satisfactory results in separating the different vegetation cover classes in the study area (Fig. 3).

Bogs proved to be problematic in the image classification. Dwarf birch Betula nana L., which grows widely on bogs, has spectral characteristics similar to those of dense mountain birch scrub on each of the three wavelength bands. The misclassification of bogs and birch forests could not be prevented with any of the tested bands, nor with the channel combination. This, together with the fact that bogs were of no special interest in
Table 1. Results of the supervised classification, red channel (2).

\begin{tabular}{lcc}
\hline & \multicolumn{2}{c}{$\%$ of image } \\
Class description & West Finnmark & Näkkälä \\
\hline 1 deflated area & 5.2 & 0.2 \\
2 lichen heath & 26.2 & 0.3 \\
3 lichen/dwarf-shrub heath & 19.9 & 0.9 \\
4 dwarf-shrub/grass heath & 21.8 & 7.1 \\
5 Empetrum-heath & 12.2 & 42.0 \\
6 mountain birch forest & 12.8 & 28.0 \\
7 bog* & 1.9 & 19.3 \\
8 water & 100.00 & 2.2 \\
Total & & 100.0 \\
\hline
\end{tabular}

* Bogs were not within the classification; a bog overlay was used

the lichen research, was the reason for using the bog overlay.

Because the natural conditions (topography, soil, climate) within the study area are quite similar on either side of the reindeer fence, the differences that occur in vegetation cover can be attributed to dissimilarities in grazing practice (Haapasaari 1988). The differences are obvious in the pixel values calculated from Finnish and Norwegian parts of the study area (Fig. 4). On the NIR channel the histograms are quite similar, but on the visible channels the Norwegian curves are skewed to bright pixels. The lack of bright, highly reflectant lichen vegetation on the Finnish side causes the absence of bright pixels and the symmetry of the curves. Comparison of the relative occupation of land cover classes within the study region also shows distinct differences in the vegetation between Finland and Norway (Table 1).

In the Näkkälä territory the largest land cover class is Empetrum-heath, while in West Finnmark the largest class is lichen and dwarf-shrub heath. Together with homogenous lichen heath, the lichen and dwarf-shrub heath class comprises $31.4 \%$ of the study area in Norway. In Näkkälä these two classes comprise only $1.2 \%$ of the area. The lichen heaths on the Finnish side are not situated on the fells as in Norway, but rather on the margins of bare deflated areas on a postglacial dune field adjacent to an esker in the southern part of the study area. According to field investigations some of this lichen heath is not a true representation. The respective pixels derived 
their reflectance values as a mean of the deflated area and the surrounding Empetrum-heath.

The reindeer fence corresponds with a sharp contrast in vegetation type, especially on the fells (Fig. 6). The impact of reindeer herding can be interpreted in more detail by comparing the vegetation classes in Norway and Finland adjacent to the fence, so that the natural conditions vary as little as possible. The Cladina heaths on the Norwegian side of the fence are considered as representing a natural vegetation cover, whereas in Finland the land cover classes represent vegetation assemblage that has been altered by grazing. The classes found on the either side of the fence are summarised in Table 2.

Variations could be detected in the classes where lichen was a dominant factor among vegetation. In Finland, the lichen heath class has changed into the dwarf-shrub and grass heath class, where the coverage of sedges and grasses (Carex spp., Festuca ovina L.) and dwarf-shrubs (Arctostaphylos alpina (L.) Sprengel, A. uva-ursi (L.) Sprengel, Betula nana L., Empetrum hermaphroditum Hagerup, Vaccinium vitis-idaea $\mathrm{L}$.) has expanded as a result of grazing (Oksanen 1978; Haapasaari 1988). Reindeer not only eat lichen, but also cause damage by trampling during summer. Henry et al. (1986) and Klein (1987) have reported an increase in the occupation of grasses and sedges after overgrazing by reindeer in North America, and Leader-Williams (1988) observed increase in the occupation of Polytrichum spp. and Poa annua in South Georgia.

Furthermore, the lichen and grass heath class has changed to either the dwarf-shrub and grass heath class or the mountain birch forest class depending on the amount and distribution of the mountain birch scrub in the area. Heaths having sparsely scattered birch scrub were difficult to detect because the ground-cover layer was clearly visible amongst scattered trees. A sparse mountain birch forest with flourishing Cladina-lichen on the ground-cover layer gives the same pixel value as lichen and dwarf-shrub heath, while the same tree density without lichen gives the value of dense mountain birch scrub. Also, the reflectance of ground-cover vegetation occupies a significant part of the pixels' reflectance values and similar spectral characteristics can be obtained with several combinations of tree density and ground-cover flora. This affected the birch forest classification, especially in Norway where lichens flourish among the trees. This can be seen in the scarcity of the mountain birch forest class (12.2\%) in Norway, even though, according to the topographic map and field checks, birch grows there as widely as it does in Finland.

\section{Discussion}

It is to be concluded that the current SPOT XS data is not entirely suitable for mapping Fennoscandian mountain heath vegetation. Multichannel combinations did not work well because of the high reflectance of both lichen and green plants on the NIR channel. In order to avoid the misclassification caused by the use of the NIR channel, only one channel was chosen for the final interpretation. In the context of this study the red channel gave satisfactory results in determining the distribution of lichen, but only on treeless areas. Scattered trees caused errors as described above. This problem could possibly be prevented by using statistical methods with which the contents of a single pixel can be estimated using multichannel information (e.g. Normalized Differentiation Vegetation Index, NDVI).

Table 2. The results of the comparison of land cover classes juxtaposed the border between Norway and Finland. The vegetation on the Norwegian side is considered as being in a natural state, whereas the Finnish side has undergone alteration because of grazing.

\begin{tabular}{|c|c|c|}
\hline $\begin{array}{l}\text { Land cover class in } \\
\text { West Finnmark (Norway) }\end{array}$ & Altered to ... & $\begin{array}{l}\text { Land cover class in } \\
\text { Näkkälä (Finland) }\end{array}$ \\
\hline Lichen heath & $\rightarrow$ & Lichen and dwarf shrub heath \\
\hline Lichen and dwarf shrub heath & $\rightarrow$ & Dwarf shrub and grass heath/Empetrum heath \\
\hline Dwarf shrub and grass heath & $\rightarrow$ & Empetrum heath \\
\hline Empetrum heath & (no alteration) & Empetrum heath \\
\hline Mountain birch forest & (no alteration) & Mountain birch forest \\
\hline
\end{tabular}




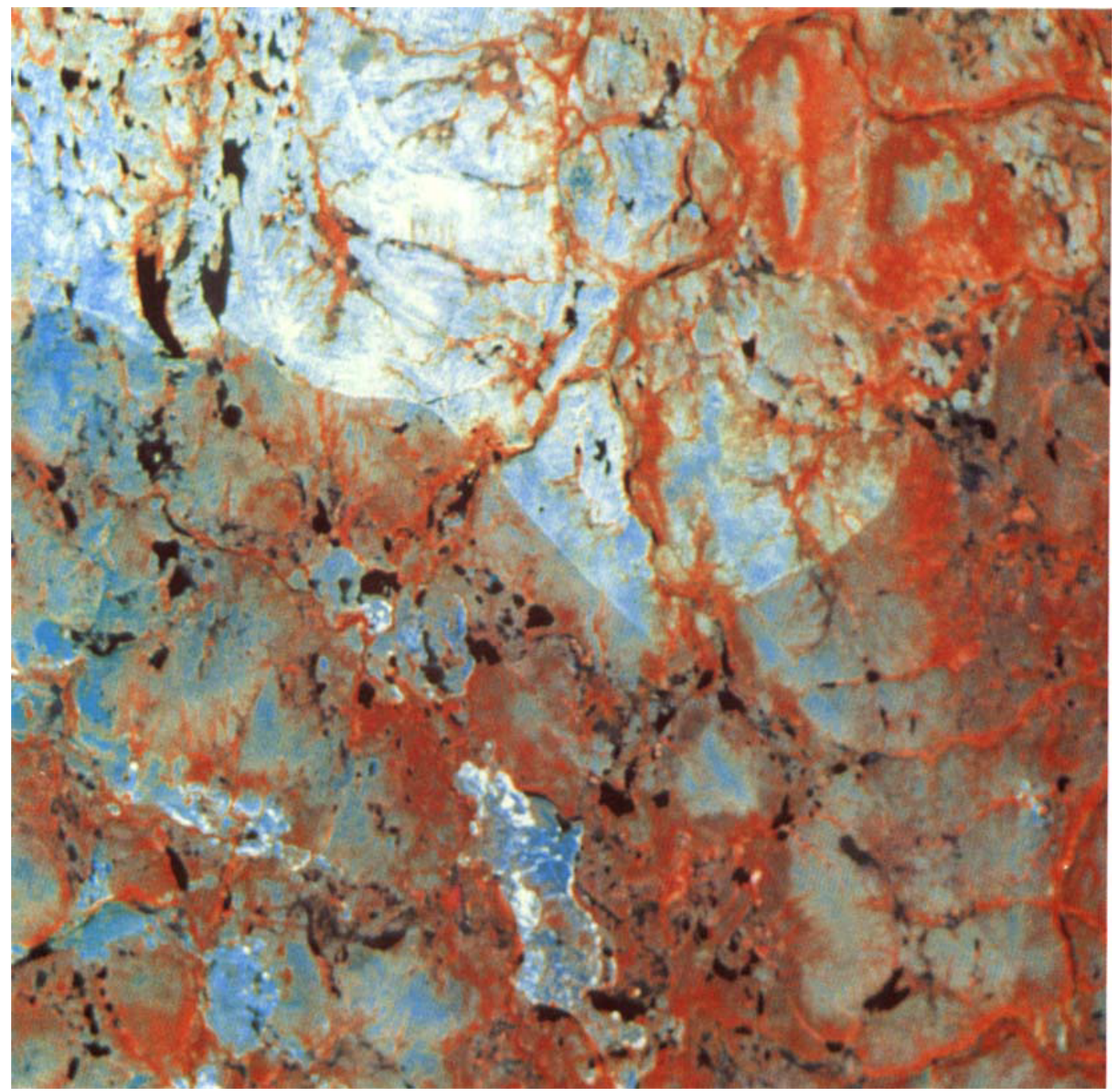

Fig. 5. False colour composite over the study area. The green channel (band 1) as green, the red channel (band 2) as blue and the NIR-channel (band 3) as red. Red areas are mainly mountain birch scrubs (Betula pubescens subsp. tortuosa (Ledeb) Nyman) or bogs with dwarf birch (Betula nana L.), cyan areas are lichen heath and greyish magenta areas are dwarf-shrub heaths without lichen and birch. The sharp contrast between Finland and Norway is well visible.

The suitability of SPOT XS data for reindeer pasture classification may be improved with the forthcoming middle-infrared spectral band of SPOT 4, scheduled for 1996 (SSC 1993). The middle-infrared spectrum $(1,300-2,400 \mathrm{~nm})$ is sensitive directly to the leaf water content in plants (Tucker 1980; Vogelmann 1990; Cibula et al. 1992; Tucker \& Sellers 1986). Combining ERS-1 radar satellite data with SPOT XS or Land- sat TM data may prove a useful method in the future.

At this stage no statistical methods were used to estimate the accuracy of the final classification. However, the fact that there is a dramatic decline in the occupation of lichen-rich land cover classes on the Finnish side of the border is significant. It is suggested that this is due to different grazing practices. 


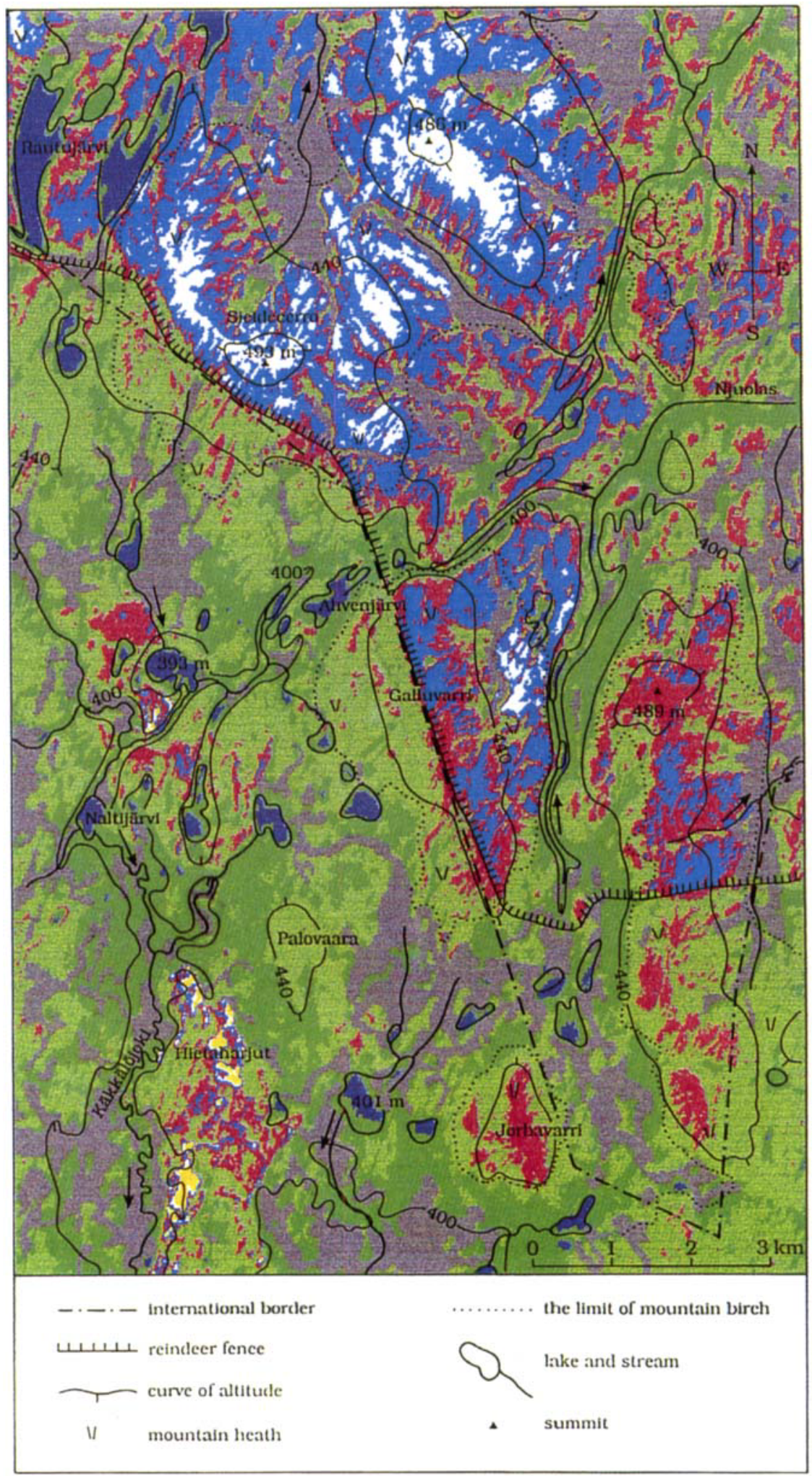




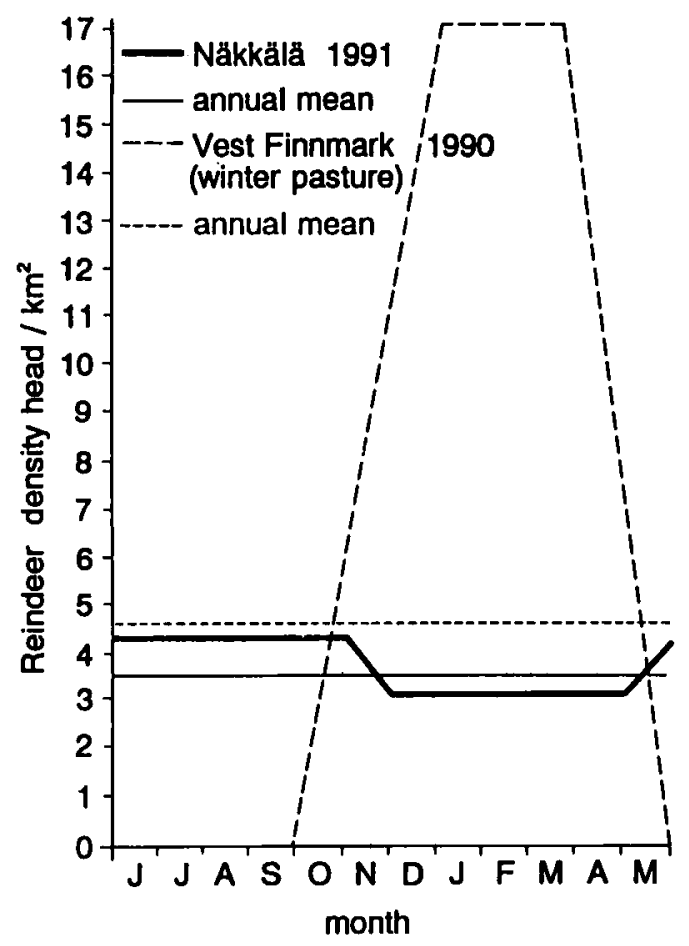

Fig. 7. A schematic diagram of the average annual grazing pressure and the density of reindeer population present during a year in the Näkkälä herding co-operative (paliskunta), Finland, and in the winter pasture of the Vest-Finnmark herding cooperative (reinbeiteområde), Norway.

The average density of the reindeer population in Näkkälä is $3 \mathrm{head} / \mathrm{km}^{2}(11,000$ animals) during winter, and $4 \mathrm{head} / \mathrm{km}^{2}$ (16,000 animals) during summer. On the winter pasture of West Finnmark, the maximum density of the reindeer population is $17 \mathrm{head} / \mathrm{km}^{2}$ (90,000 animals). The first reindeer may arrive on the winter pasture on 1 October and the whole population grazes in the area from 31 December to 15 March. From 31 May until autumn, no reindeer should remain on the winter grazing land. A mean grazing pressure caused by reindeer can be calculated as a function of number of animals per area per unit of time (Oksanen 1978). The grazing pressure in Näkkälä is $3.5 \mathrm{head} / \mathrm{km}^{2} / \mathrm{a}$, while in the winter pasture of West Finnmark it is between 3.5 and 11 head/ $\mathrm{km}^{2} / \mathrm{a}$, depending on the speed at which the popu- lation migrates seasonally to and from the area. A simple arithmetic average based on linear growth and decline of population in time on the winter pasture is $4.6 \mathrm{head} / \mathrm{km}^{2} / \mathrm{a}$ (Fig. 7). Thus the annual grazing pressure on the winter pasture of West Finnmark is approximately $30 \%$ higher than in Näkkälä.

It is therefore assumed that the obvious deterioration of the lichen vegetation on the Finnish side of the reindeer fence is not necessarily a consequence of excessive numbers of reindeer (too high annual pressure), but rather of lack of seasonal grazing practice. Reindeer destroy the natural Cladina heaths by grazing in the area during the summer. It is recommended that the reindeer should be kept away from lichen heaths during snow-free season in Finland also, so that the vital winter forage would not be destroyed by trampling.

Acknowledgements. - Assistance in the field work was given by $\mathbf{K}$. Tanila-Pellikka. R. Virtanen, Department of Botany, University of Oulu, determined some plant species. We want to also express our heartfelt gratitude to 2 anonymous referees, $P$. Worsley and $M$. Duffy for improvements on the manuscript, and to R. Bryant, V. Erfurt, P. Numminen and P. Schade for assistance with the illustrations.

\section{References}

Cibula, W. G., Zetka, E. F. \& Rickman D. L. 1992: Response of thematic mapper bands to plant water stress. Int. J. Remote Sensing 13, 1869-1880.

Ferguson, R. S. 1991: Detection and classification of muskox habitat on Banks Island, Northwest Territories, Canada, using Landsat Thematic mapper data. Arctic 44 (Suppl. 1), 66-74.

Haapasaari, M. 1988: The oligotrophic heath vegetation of northern Fennoscandia and its zonation. Acta Botanica Fennica 135, 1-219.

Henry, G., Freedman, B. \& Svoboda, J. 1986: Survey of vegetated areas and muskox populations in east-central Ellesmere Island. Arctic 39, 78-81.

Henry, G., \& Gunn, A. 1991: Recovery of tundra vegetation after overgrazing by caribou in Arctic Canada. Arctic 44, 3842.

Hodanova, D. 1985: Leaf optical properties. Pp. 107-127 in Sestak Z. (ed.): Pholosynthesis During Leaf Development. Dr. W. Junk Publishers, Prague.

Hämet-Ahti, L. 1963: Zonation of the mountain birch forests in the northernmost Fennoscandia. Annales Botanici Societatis Zoologicae Botanicae Fennicae 'Vanamo' 34(4). 127 pp.

Johansen, B. \& Tømmervik, H. 1990: Mapping winter grazing

Fig. 6. Land cover classification of the study area. Dark blue $=$ water, grey $=$ mire, dark green $=$ mountain birch forest, light green $=$ Empetrum-heath, red $=$ dwarf-shrub and grass heath, blue $=$ lichen and dwarf-shrub heath, white $=$ lichen heath, yellow $=$ deflated area. 
areas for reindeer in Finnmark county, Northern Norway, using Landsat 5-TM data. Abstracts of IGARSS'1990, the IOth annual International Geoscience \& Remote Sensing Symposium, Washington D.C., U.S.A. May 20-241990. Pp. 613616.

Klein, D. R. 1987: Vegetation recovery patterns following overgrazing by reindeer on St. Matthew Island. $J$. Range Manage. 40, 336-338.

Kujansuu, R. 1967: On the deglaciation of western Finnish Lapland. Bulletin de la Commission Geologique de Finlande $282.98 \mathrm{pp}$.

Käyhkö, J. 1991: Aeolian processes on Hietatievat dune field, Enontekiö municipality, NW Finland. Master's thesis (in Finnish). Dept. of Geography, Univ. of Helsinki. $166 \mathrm{pp}$.

Leader-Williams, N. 1988: Reindeer on South Georgia. Cambridge University Press, Cambridge.

Matthews, S. B. 1991: An assessment of bison habitat in the Mills/Mink Lakes area, Northwest Territories, using Landsat Thematic Mapper data. Arctic 44 (Suppl. 1), 75-80.

Nieminen, M. \& Kumpula, J. 1991: Porolaidunten kartoitus onnistuu satelliittikuvien avulla. Poromies 1991(2), 28-32.

Oksanen, L. 1978: Lichen grounds of Finnmarksvidda, Northern Norway, in relation to summer and winter grazing by reindeer. Rep. Kevo Subarctic Res. Stat. 14, 64-71.

Olsson, B. 1957: Om flygsandfälten på Hietatievat i östra Enontekiö. Terra 69, 129-137.
Pearce, C. M. 1991: Mapping muskox habitat in the Canadian High Arctic. Arctic 44 (Suppl. 1), 49-57.

Rantanen, M., Tomppo, E., Nenonen, S. \& Nieminen, M. 1989: Porolaidunten inventointi kaukokanoitusta käyttäen. Research report. Riista- ja kalatalouden tutkimuslaitos, Porotutkimusyksikkö, Rovaniemi, Finland.

Satterwhite, M. B., Henley, J. P. \& Carey, J. M. 1985: Effects of the lichens reflectance spectra of granitic reflectance surfaces. Remote Sensing of Environment 18, 105-112.

Seppälä, M. 1966: Recent ice-wedge polygons in Eastern Enontekiö, Northernmost Finland. Publicationes Instituti Geographici Universitatis Turkuensis 42, 273-287.

SSC 1993: Remote sensing 23, 3. Swedish Space Corporation, Solna, Sweden.

Tucker, C. J. 1980: Remote sensing of leaf water content in the near infrared. Remote Sensing Environ. 10, 23-32.

Tucker, C. J. \& Sellers, P. J. 1986: Satellite remote sensing of primary production. Int. J. Remote Sensing 7(11), 1139-1416.

Tømmervik, H. \& Lauknes, I. 1987: Kartlegging av reinbejter ved hjelp av Landsat 5/TM data i Kautokeino, Nord-Norge. Rangifer 7, 2-14.

Vogelmann, J. E. 1990: Comparison between two vegetation indices for measuring different types of forest damage in the north-eastern United States. Int. J. Remote Sensing 11, 22812297. 